\title{
Macroinvertebrate communities in sediment and plants in coastal Mediterranean water bodies (Central Iberian Peninsula).
}

\author{
M. Sahuquillo*, J.M. Poquet, J. Rueda, M.R. Miracle \\ Departament de Microbiologia i Ecologia, Facultat de Biologia, Universitat de València, E-46100 Burjassot, València, Spain.
}

\begin{abstract}
Sediment and plant-associated macroinvertebrates were sampled in six shallow water bodies along the central part of the coast of Mediterranean Spain. The size of ponds, salinity and hydroperiod were highly variable. Seventy-one taxa were recorded, some of them were endemic or uncommon species, evidencing the important contribution of these ponds to biodiversity. Crustaceans and gastropods of biogeographical interest were found in the most primeval site. Correspondence analysis showed that macroinvertebrate assemblages responded to environmental variables such as salinity, temporality and eutrophication. The brackish water fauna was dominated by crustaceans, while oligochaeta and insect larvae were abundant in freshwater conditions. Oligochaetes were abundant at localities with high trophic level, whereas localities with semi-permanent waters were dominated by chironomids. The density of macroinvertebrates was clearly related with trophic state but we did not find significant relationships between density and salinity or water permanence. For plant associated samples our results showed negative relationships between species richness and temporality or salinity, contrary to sediment samples, where the Oligochaeta/Chironomidae ratio in sediments and the percentage of sensitive taxa (Ephemeroptera, Odonata, Trichoptera) were useful indices, and were dependent on pond typology. This study emphasizes the broad ecological variety of ponds found in these wetlands and their importance for biodiversity. Some ponds act as permanent biodiversity reservoirs in fluctuant marshes with seasonal dryness, calling for more attention on their ecological relevance for management strategies.
\end{abstract}

Keywords: Mediterranean coastal ponds, macroinvertebrates, biodiversity, salinity

\section{Introduction}

Mediterranean wetlands are complex systems now remnants from what were once a series of multiple extensive and rich shallow aquatic ecosystems, forming a landscape of marshlands and lagoons along the coast. The natural evolution of this landscape has been modified by human activity in various ways. Drainage has transformed these primary extensive areas of continuous wetlands into fragmented small ponds and ditches surrounded by agricultural areas; modifications of natural hydrology have altered salinity and hydroperiod length and disconnected water habitats, including their relationship with the sea; inflow of sewage waters and pesticides have promoted eutrophication. Moreover excessive regulation of water fluxes and modifications for irrigation have changed the hydrological regime of the wetlands into systems without seasonal changes and with more fluvial influences. However they still preserve a diverse and singular fauna and measures of restoration are now being promoted in most countries (Oertli et al. 2005).

*Corresponding author: maria.sahuquillo@uv.es
Shallow aquatic ecosystems typically support a wide range of communities. If they have adequate light penetration, then submerged plant beds develop (Moss et al. 1997) and aquatic macroinvertebrates proliferate. However through eutrophication (overlaying phytoplankton shading), pesticide use and other perturbations, aquatic plants may become scarce or disappear. The role of aquatic plants is very important for maintaining the functioning and biodiversity of these ecosystems (Scheffer 1998), especially for macroinvertebrates. Macroinvertebrates form an important component of shallow lake ecosystems occurring in the sediment and in the water column, mainly among submersed macrophytes, and they are important components of food web interactions, including fish and birds (McQueen et al. 1986, Cyr \& Downing 1988, Batzer et al. 1993). Although information exist (Kornijów 1989), investigation is still needed about the distribution of macroinvertebrates in relation to the typology and ecological status of ponds.

This study is part of a pan-European project (ECOFRAME) which tried to test a typology and classification system for shallow lakes according to the require- 
ments of the European Water Framework Directive (Moss et al. 2003). Among 28 variables for the determination of the ecological status of shallow lakes, some macroinvertebrate indices were examined with different sampling techniques. In the present study, we focussed on the macroinvertebrate communities of sediment and aquatic plants habitats in six Mediterraneen water bodies with different characteristics. The aims of this work were thus: (1) to study the specific composition of macroinvertebrate communities in Mediterranean wetlands in order to bring out pond typologies and biological indices, and (2) to compare the macroinvertebrate communities living in sediment and in plant habitats, with particular attention to trends in density and species richness in response to environmental variability and human impacts.

\section{Study area}

Six water bodies were chosen along $220 \mathrm{~km}$ of West Mediterranean coast of the Valencian Community, representing a range of high to poor ecologicalstatus based on previous testing (Moss et al. 2003). The water bodies also differed in salinity and water permanence, beside trophic status.

(1) Charca del Pozo (CBN) is a peat exploitation pond included in a protected marshland (Prat de CabanesTorreblanca) close to the sea. The marsh originates from a land-filled coastal Holocene lagoon. Considerable parts of this wetland are peat-lands which have been excavated since the end of the $19^{\text {th }}$ century for peat exploitation. Despite this, it could be considered as the best preserved marshland in the Valencian Community. Water is clear with an important development of submerged macrophytes (mainly Chara).

(2) The largest site is the Albufera of Valencia (ALB), a lagoon of 2.800 ha surrounded by 14.000 ha of rice fields located in the protected area of Albufera Natural Park. It is mainly fed by freshwater inflows of surface waters from irrigation surplus. By 1960, this lagoon lost its submerged plant beds and shifted to a turbid state. It is now a hypertrophic shallow lake dominated by planktonic filamentous cyanobacteria. Only emergent macrophytes were found in the lagoon (reeds, cattail), while an isolated Potamogeton fluitans shoot was found at the mouth of the Dreta Channel.

(3) Baldoví pool (BAL) is one of a series of spring ponds located in the Albufera National Park, in the Valencia coastal plain. It has a high water flow fed by subterranean karstic waters of constant tempera- ture and mineral contents. Although it periodically suffers from the impact of contamination from surrounding rice fields, it is still in a clear state and maintain a notable extension of different species of submerged macrophytes (Phanerophytes).

(4) Cap de Terme (CPT) is a small pond excavated for drainage purpose in a highly modified wetland (agricultural activities) called La Safor Marsh (2000 m from the sea). The inflow of the pond is due to nearby springs and irrigation surplus, which promote its highly eutrophic status. However, at the time of sampling this pond still had a rich macrophyte cover (Phanerophytes).

(5) Rini (XER) is a small pond recently restored to create a natural reserve near Xeresa for an endemic fish ( $\mathrm{Va}$ lencia hispanica). In contrast to the former pond in the same area, XER is shallow and doesn't have spring water inflows. Seasonal water level varied markedly due to groundwater extraction in the agricultural neighbouring and can get dry in some years. At the time of sampling it had a dense Chara bed.

(6) The most southern site is the semi-natural pond Charca Sud Oeste (HON) situated in the protected wetland area of El Hondo Natural Park. It is the remnant of an ancient shallow lake (distance to the sea: $12000 \mathrm{~m}$ ) that was excavated to construct two small shallow reservoirs for irrigation purpose. The study site is one of the ponds that surround these reservoirs. They have no communication with them and are mainly fed by irrigation surplus. Agriculture waters in this arid area are continuously reused, increasing salt concentration and water level fluctuations. At the time of the sampling it was covered by an extremely dense Chara bed.

All studied sites are connected with other water bodies through a wide net of ditches and channels, which is a common feature of all wetlands in this area. This characteristic is important because it allows the migration of aquatic animals, including fishes, and also because many organisms can find refuge in the deeper ditches during low water periods. From these systems, re-colonization is possible when water level increases again.

The main characteristics of these locations are shown in Table 1. Chemical and biological variables were measured from samples collected simultaneously with macroinvertebrate, and analysed by researchers of the ECOFRAME consortium (Moss et al.2003, Blanco et al. 2003). The study sites can be categorized as hypereutrophic (ALB), eutrophic (CPT), mesotrophic (HON) and oligo-mesotrophic (XER, BAL, CBN), according to the mid-summer values of total phosphorous and chlorophyll- $a$ (OECD, 1982). 


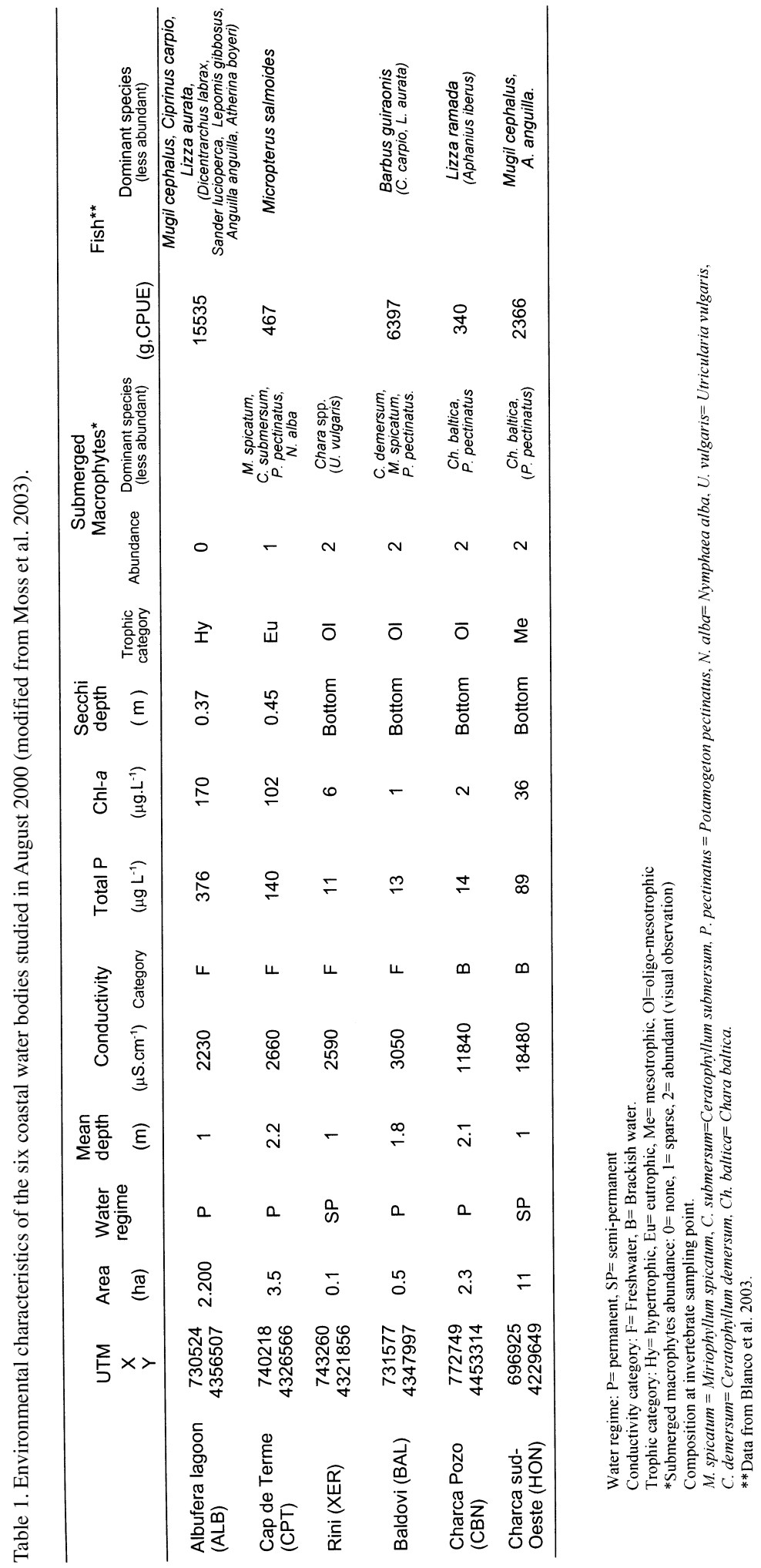




\section{Macroinvertebrate sampling}

The sampling design responds to the aim of the ECOFRAME project, i.e. to include a wide number of biological groups and habitats in each location, which are sampled only once. The selected locations were sampled between 26 July and 7 August 2000. At each location 10 sampling points were selected for sediment macroinvertebrates at a depth of about one meter, covering the whole perimeter of the lake, except in the case of the large ALB where sampling points were distributed along a transect through its south-eastern part. At 5 of these points plant associated macroinvertebrates were also collected, considering all the macrophyte associations of each site (submerged as well as emergent). Quantitative samples of sediment were collected using a cylindrical tube (Moss et al. 2003) with an internal diameter of $5 \mathrm{~cm}$, taking a core to a depth of $10 \mathrm{~cm}$. Sediment samples were preserved in $4 \%$ formaline in the field, and then sieved in the laboratory through $240 \mathrm{~mm}$ mesh. Semiquantitative samples of plant associated macroinvertebrates were collected by sweeping a standard hand-net (Acc FBA $915 \mathrm{~mm}$ circ., mesh size $240 \mu \mathrm{m}$ ) among macrophytes, covering a distance of 2 meters, at a depth ranging from 0.5 to $1.0 \mathrm{~m}$ below the surface. All samples were preserved in $4 \%$ formaldehyde.

Animals were sorted from the sediment and from plant material under a dissecting microscope in the laboratory. They were counted and identified to the lowest taxonomic level, whenever possible. For sediment samples density referred to an area of the bottom $\left(\mathrm{dm}^{2}\right)$, and for plant samples as individuals per sample.

\section{Statistical analysis}

To clarify the distribution patterns of macroinvertebrates, a Detrended Correspondence Analysis (DCA) was used to analyse the relative abundances of all taxa at family level. Prior to analysis, proportions $(p)_{i}$ of the different taxa were transformed by means of arcsen $\sqrt{ } p_{i}$ transformation.

An index of floral originality (IFO) was used to evaluate the different macroinvertebrate fauna among sites (Puchalski 1987),

$$
\text { I.F.O. }=\left(\sum_{i=1}^{\mathrm{s}} 1 / \mathrm{M}_{i}\right) / \mathrm{S}
$$

where $M_{i}$ is the number of localities where species $i$ occurs and $S$ is the number of species of the corresponding locality.

Since abundance, species richness and some ratios of taxonomical groups respond strongly to trophic condi- tions in wetlands (Cyr \& Downing 1988, Kornijów et al. 2003) we compare the studied locations in relation to these system descriptors. Density, species richness and diversity (according to Shannon \& Wiener function) were calculated for each sample. Additionally, for each site and each habitat (sediment or macrophytes), taxa richness (mean and variance) has been estimated by the jackknife approach (Heltshe \& Forrester 1983). The mean value of diversity index and its standard error were calculated by the jackknifing method (Zahl 1977). One-way ANOVA was used to test the differences between these descriptors among study sites. Densities were log-transformed prior to analysis to meet the assumptions of ANOVA. Significant results of ANOVA were further explored with post-hoc Tukey and GamesHowell tests. All the statistical analyses were carried out with SPSS 12.0 except for the DCA ordination that was performed using the program Multivariate Statistical Package (MVSP 3.0 for Windows).

\section{Results}

\section{Macroinvertebrates taxa and communities}

A total of seventy macroinvertebrate taxa (Table 2) were collected in sediments and in macrophytes at the six study sites (50\% identified to species level). In general, insects dominated the assemblage, either in the number of different taxa (31 insect taxa, i.e., 44\%) or quantitatively, with a relative abundance of $48 \%$ for sediment macroinvertebrates and $49 \%$ for plant associated ones. In general, the highest densities of each taxa were related to the highest frequency of occurrence the most abundant taxa were thus found in most samples. The index of floral originality (Table 2) applied to macroinvertebrates evidenced the singularity of locations such as BAL and XER.

Differences between macroinvertebrate groups among the studied locations were very important (Fig.1). Chironomidae and Oligochaeta showed higher relative abundances in freshwater sites while crustaceans and gastropods dominated in brackish and less eutrophic waters. Oligochaeta dominated in freshwater with high trophic level: (ALB and CPT). In contrast, Oligochaeta were almost absent in the semi-permanent sites XER and HON, where Chironomidae were the most abundant group. Crustaceans were the most abundant group in the well preserved locations BAL and CBN.

With respect to the type of habitat sampled, there were also important differences (Table 2). A total of 43 taxa were identified in sediment samples, and 55 were found in the plant samples. Seven taxa were found exclusively in sediments, most of them belonging to 
Table 2. Density (D, ind $/ \mathrm{dm}^{2}$ for sediment samples and ind/sample for plant associated ones) and percentage of occurrence (Fr) of each macroinvertebrate taxa. Endemic or unusual species are underlined. For each location and sample type the index of floral originality (I.F.O.; Puchalski 1987) is also indicated.

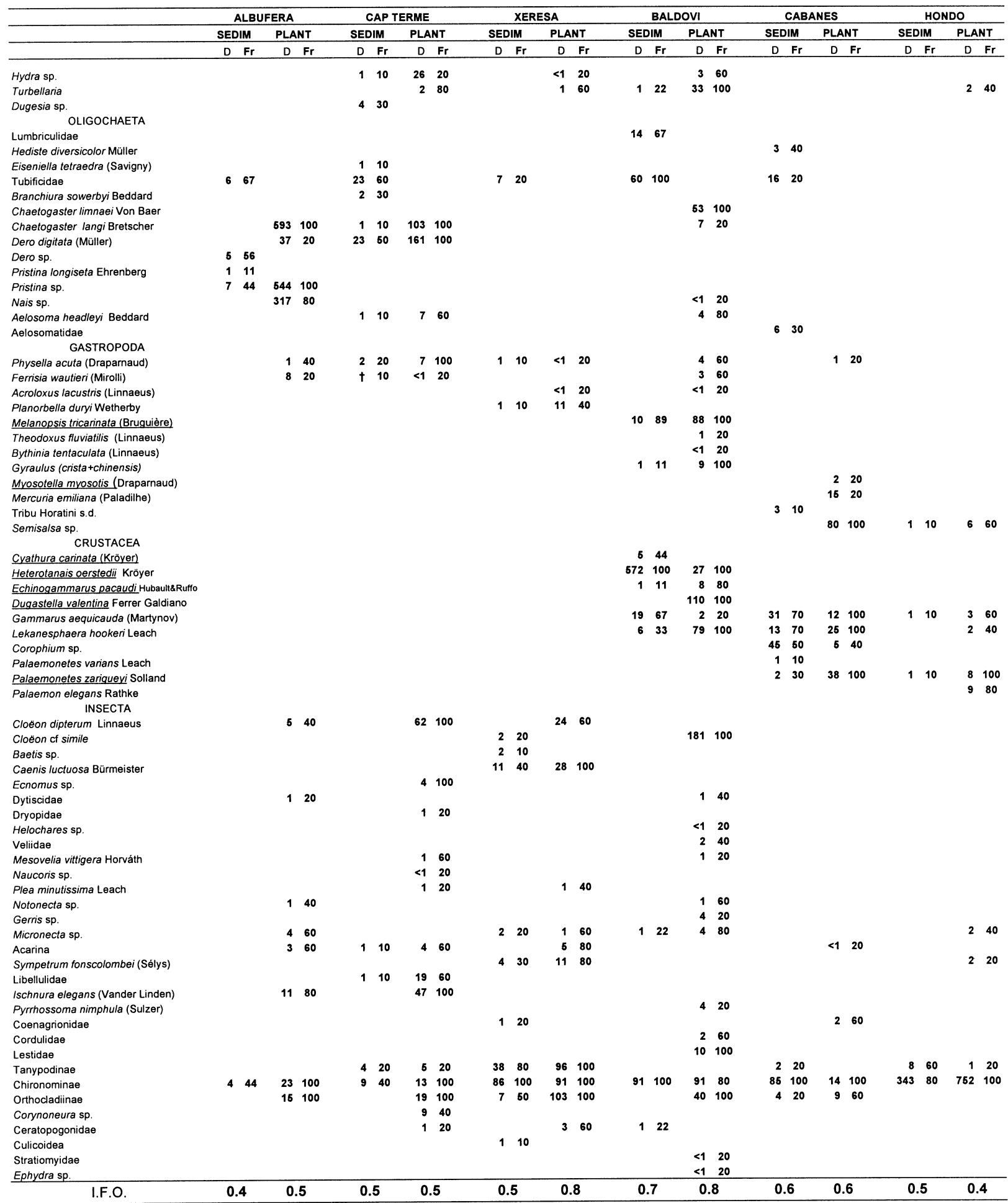


SEDIMENT

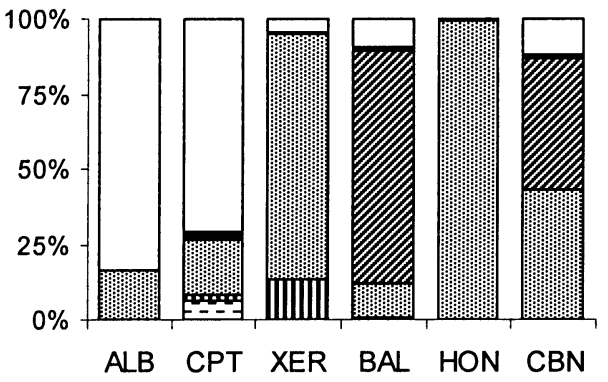

PLANT

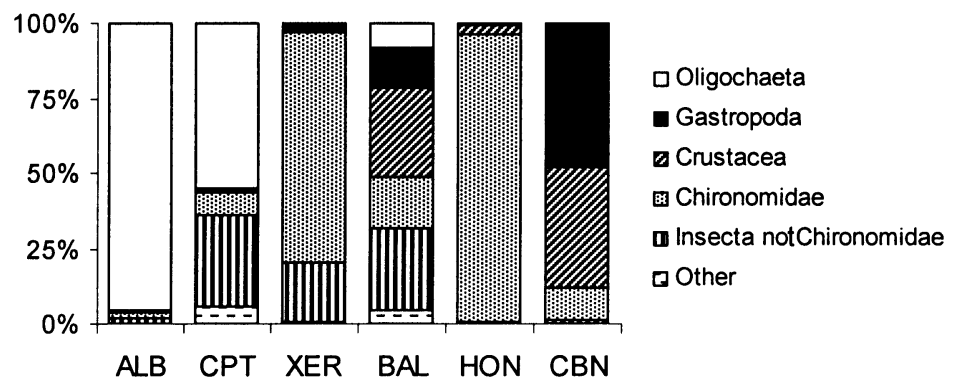

Fig. 1. Relative abundances of macroinvertebrate groups collected from six coastal water bodies in two different habitats (sediment and plants) in Aug 2000. ALB, Albufera; CPT, Cap de Terme; XER, Xeresa; BAL, Baldovi; HON, Hondo; CBN, Cabanes, ordered by salinity (left = low, right $=$ high) and descending trophy.

the Oligochaete group (Tubificidae, Lumbriculidae, Hediste diversicolor, Branchiura sowerbyi and Eiseniella tetraedra) or to crustaceans (Cyathura carinata). On the other hand, Chaetogaster spp., Dugastella valentina, Echinogammarus pacaudi and all the members of Heteroptera, Zygoptera and Gastropoda were more frequent in plants than in sediments. Chironomidae were present in each habitat and each water body. The Orthocladiinae and Chironomiinae subfamilies reached their highest densities and frequencies of occurrence in plants and in sediments, respectively.

The study sites differed in sediment macroinvertebrates: in the more temporary sites and/or saline sites (XER, HON and CBN), Chironomini made up about $50 \%$ of total sediment macroinvertebrate density, whereas in the more eutrophicated, permanent, freshwater sites (ALB and CPT) this taxa represented only $15 \%$ while Oligochaeta was the most important group. In BAL the community of the sediment was markedly distinct and the richest. Beside Oligochaeta and Chironomidae, which were present in similar proportions, this community was dominated by crustaceans, mainly Heterotanais oerstedii (73\%), but also Cyathura carinata and Gammarus aequicauda.

Plant associated macroinvertebrates were different among locations; crustaceans and gastropods clearly differentiated brackish from freshwater habitats and, within the latter, the hyper and eutrophic sites from the oligotrophic ones. However, among freshwater sites, the macroinvertebrate assemblages associated to macrophytes were more similar than those associated to sediments.

The first two axes of the DCA applied to the relative abundances of macroinvertebrate families explained a $36 \%$ of the overall variance. The first axis (Fig. 2a) clearly separates assemblages belonging to fresh or brackish waters. Euryhaline crustaceans and gastropods (Palaemonidae, Corophiidae, Hydrobiidae) are located at the highest positive values, whereas most insect larvae, typical of freshwaters, are grouped on the opposite side. The second axis reflects differences related to hydrology, and probably water quality. The families characteristic of the freshwater spring showed the highest positive values (Melanopsidae among gastropods and Atyidae and Anthuridae among crustaceans). Insects and crustaceans found in permanent waters had intermediate values, whereas lower values of the axis grouped taxa of more opportunistic and widespread occurrence, such as subfamilies of chironomidae and some families of insects (Ephemeroptera and Libellulidae).

The representation of the samples in the DCA plane (Fig. 2b), confirms the above mentioned interpretation of the axes. Sites are distributed along the first axis separating eutrophic freshwaters (ALB, CPT) at the left side and brackish ones (CBN, HON) to the right edge. $\mathrm{BAL}$ is located in the centre due to its low trophy, but also moderate chloride concentration $\left(736 \mathrm{mg} \mathrm{L}^{-1} \mathrm{Cl}^{-}\right.$). XER occupies an intermediate position probably because of its low trophy and high evaporation rate. With respect to the second axis, semi-permanent sites (XER and HON) are grouped at the lower values, and are opposed to the permanent waters of the spring pool BAL that is located at the highest positive edge of this axis. Highly eutrophic and permanent sites (ALB and CPT) are in an intermediate position. These results suggest that the larger locations with permanent waters have a higher spatial heterogeneity than the semi-permanent sites XER and HON, because the samples of the latter sites are more aggregated. Data also evidenced that sediment macroinvertebrates have a higher dispersion within a locality than the plant associated ones, and that they discriminate more sharply the different locations than plant associate ones. 
a)

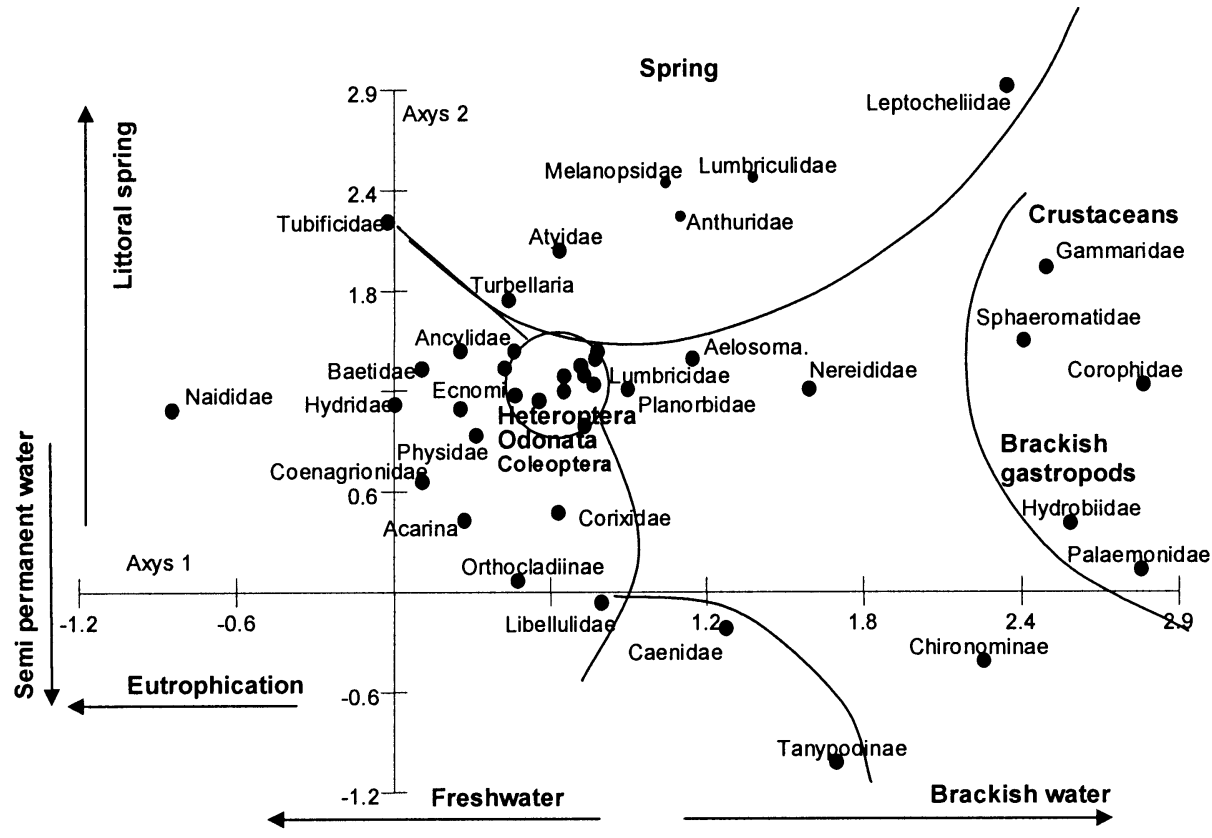

b)

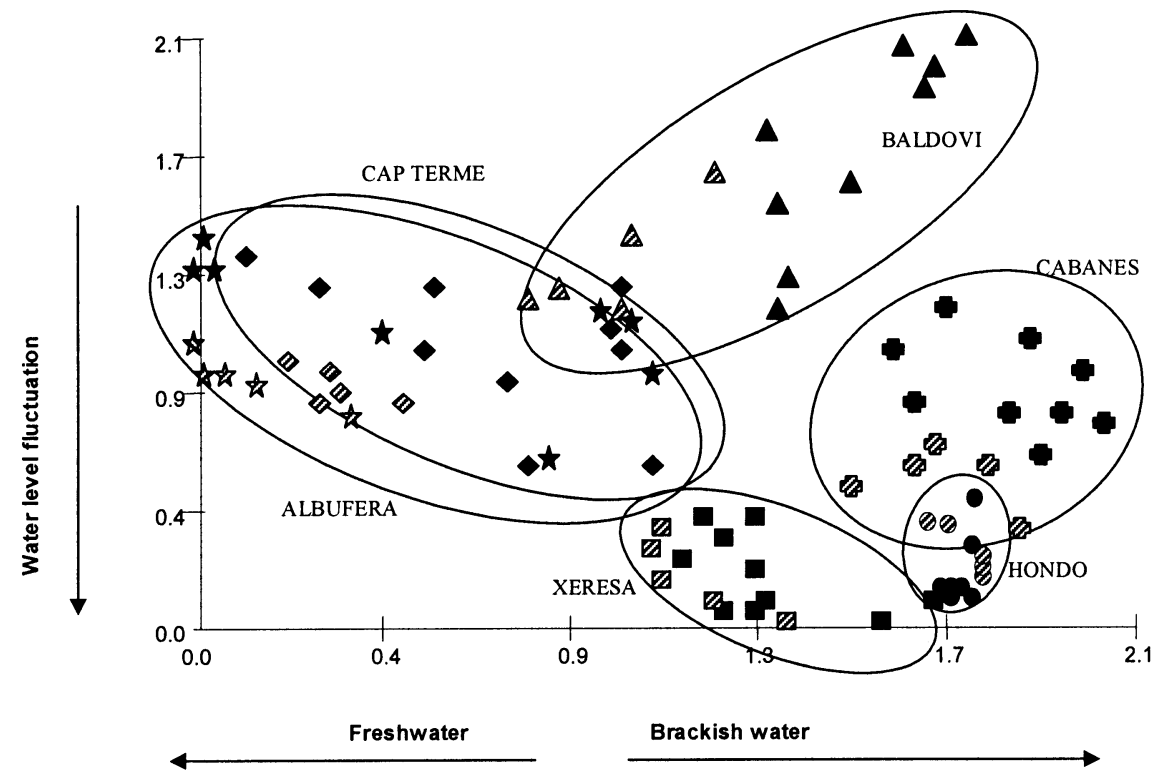

Fig. 2. Detrended Correspondence Analysis (DCA). Ordination in the space defined by the two first axis of: (a) the different families of macroinvertebrates and (b) the sample scores, the samples from each site are indicated by a different symbol, solid for sediment samples and striped for samples taken among plants. Families are encircled to show main assemblages. Families of Heteroptera, Odonata and Coleoptera, indicated by a circle but not labelled because they came too close together, are: Veliidae, Mesoveliidae, Naucoridae, Pleidae, Corixidae, Notonectidae, Libellulidae, Coenagronidae, Lestidae, Cordulidae, Dytiscidae, Dryopidae, Hydrophilidae. 
Table 3. Results from univariate one way ANOVA for some system variables. Tukey (or Games-Howell, G-H) post-hoc comparisons are shown by grouping together the sites whose means were not significantly different at the 0.05 level. Site groups are ordered by increasing means. ALB, Albufera; CPT, Cap de Terme; XER, Xeresa; BAL, Baldovi; HON, Hondo; CBN, Cabanes.

\begin{tabular}{|c|c|c|c|c|c|c|c|c|}
\hline & \multicolumn{4}{|c|}{ Sediment samples } & \multicolumn{4}{|c|}{ Plant associated } \\
\hline & d.f. & $\mathrm{F}$ & $p$ & Post hoc & d.f. & $\mathrm{F}$ & $p$ & Post hoc \\
\hline $\begin{array}{l}\text { Density } \\
\text { (log transformed) }\end{array}$ & 5 & 9.515 & $* * *$ & $\begin{array}{l}\text { ALB-CPT } \\
\text { XER-CBN-HON } \\
\text { HON-BAL }\end{array}$ & 5 & 1.481 & ns & -- \\
\hline Species richness & 5 & 8.437 & $* * *$ & $\begin{array}{l}\text { HON-ALB-CPT } \\
\text { CPT-XER-CBN } \\
\text { CBN-BAL }\end{array}$ & 5 & 25.308 & $*$ & $\begin{array}{l}\text { HON-CBN-ALB-XER } \\
\text { CPT } \\
\text { BAL }\end{array}$ \\
\hline Diversity & 5 & 3.989 & $* *$ & $\begin{array}{l}\text { HON-ALB-CPT } \\
\text { BAL-XER-CBN }\end{array}$ & 5 & 25.391 & $* * *$ & $\begin{array}{l}\text { HON } \\
\text { ALB-CBN-XER } \\
\text { XER-BAL-CPT }\end{array}$ \\
\hline $\begin{array}{l}\text { Jackknifing } \\
\text { diversity }\end{array}$ & 5 & 1085.175 & $* * *$ & $\begin{array}{l}\text { HON } \\
\text { BAL } \\
\text { ALB-XER } \\
\text { CBN-CPT }\end{array}$ & 5 & 529.213 & $* * *$ & $\begin{array}{l}\text { HON } \\
\text { ALB } \\
\text { CBN-XER } \\
\text { CPT } \\
\text { BAL } \\
\end{array}$ \\
\hline
\end{tabular}

${ }^{* * *} \mathrm{p}<0.001,{ }^{* *} \mathrm{p}<0.01,{ }^{*} \mathrm{p}<0.05, \mathrm{~ns}=$ not significant

\section{Density, diversity and species richness}

Density of sediment macroinvertebrates showed an increasing trend when study sites were arranged according to a decreasing trophic level, their variability being higher in the waters with intermediate trophy. However for plant associated macroinvertebrates the differences in density among sites were not significant (Table 3, Fig. 3a). Variability between densities from plant associated macroinvertebrates within the same site was important, especially in extreme conditions like the hypertrophic ALB and the semi-permanent HON. In ALB, the highest density of plant-associated macroinvertebrates was observed in the only sample where an isolated single plant of a submerged macrophyte was found (Potamogeton fluitans, 6000 ind. per sample). The huge difference between this and the other samples, although the method used was only semi-quantitative, indicates that important differences exist between samples taken within submerged/floating macrophytes or within emergent plants (Typha, Phragmites).

Species richness and diversity of sediment macroinvertebrates also significantly differed among sites. The post-hoc tests separated the group of hyper to mesotrophic sites (ALB, CPT and HON) with lower diversity and species richness from the oligotrophic ones (CBN and BAL) (Table 3). When Jackknifing estimator of diversity was applied, its values were clearly higher than the sample mean diversity, except in BAL and HON (Fig. 3c). In these sites, sediment macroinvertebrate densities were high and homogenously dominated by one population $(H$. oerstedii in the case of BAL and chironomini in the case of $\mathrm{HON}$ ), and although the number of species increased with the number of samples collected, indicated by a high Jackknifing estimator of species richness, the dominant species was the same in all samples resulting in an invariable diversity spectrum. When post hoc test were applied with the jackknife estimators the significance of the multicomparisons increased but the site of BAL was displaced because its diversity did not increase by pooling the samples.

For plant associated macroinvertebrates, species richness and diversity also differed significantly among the sites. In this case, species richness and jackknife estimate of diversity gave very similar results. The post-hoc multicomparisons with the jackknife estimates were also more significant than with the sample diversity values. The freshwater permanent sites (CPT, BAL) presented higher number of species and diversity (Table 3), showing again HON and ALB the lower values of these descriptors. 
a)
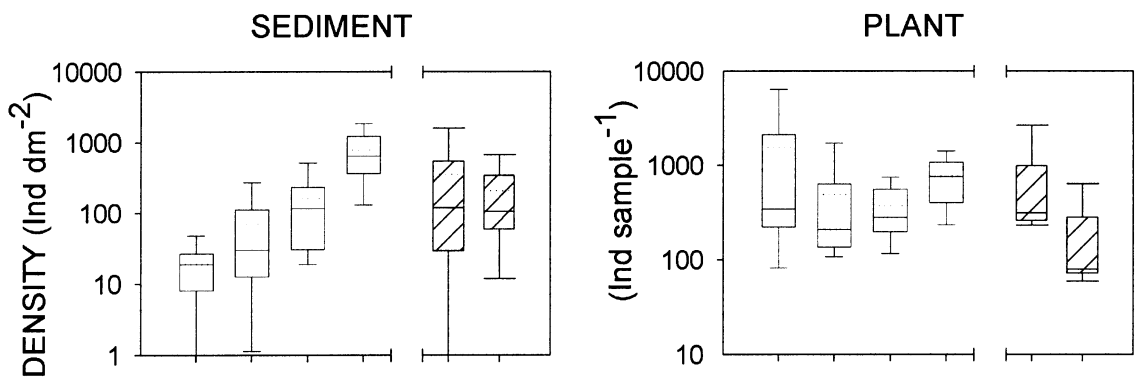

b)
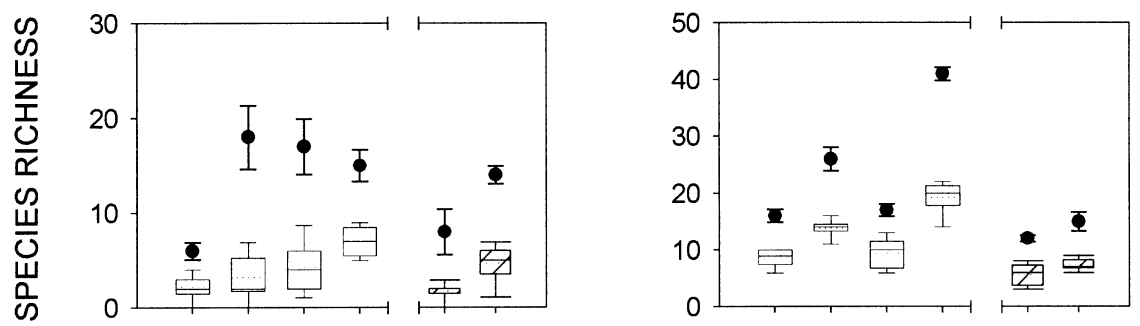

c)
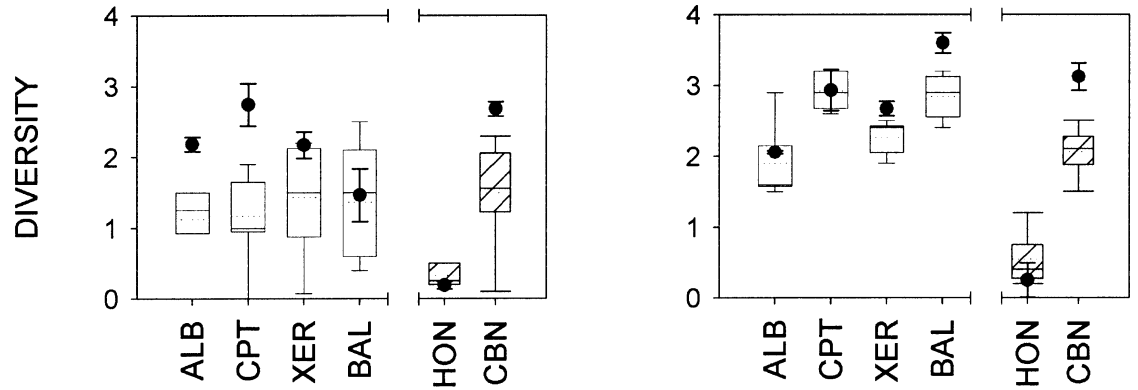

Fig. 3. Macroinvertebrate density in log scale (a), number of species (b) and Shannon diversity (c) in sediment $(n=10)$ and plant associated samples $(n=5)$ in the six water bodies studied. Box-plots with median (solid line), mean (dotted line) and quartiles and whiskers (highest and lowest values) for each locality assembled in freshwater (white box-plots) and saline (striped box-plots) groups, and in order of decreasing eutrophication within these groups. Jackknife $1^{\text {st }}$ order estimate of species richness (estimate \pm variance) (b) and jackknife estimate of Shannon diversity index (estimate \pm standard error) (c) are also indicated for each locality and habitat by scatter plots with error bars. Sites are coded as in figure 1 .

The species richness and the diversity index were significantly higher (one-way ANOVA, one factor with two levels, $\mathrm{p}<0.001$ ) in plant associated samples when compared with sediment ones (Figs. 3b and 3c).

Ratios between macroinvertebrate groups that have been used as quality indices are plotted in Fig. 4. They also depend on other environmental conditions beside trophic level, as for the system variables just described. Concerning to percentage of Chironomidae, the two sites with a more fluctuant water level (XER and HON) presented a higher relative abundance of this group, but no clear relation to eutrophication was obtained.
The Chironomini group was dominant in all sediment samples, and largely in brackish sites. The ratio oligochaetes:chironomids, used to characterized freshwater lake sediments, showed the expected increase with increasing trophic level, but oligochaetes were scarce or even absent in some locations, i.e. the semi-permanent and brackish ones. The index of sensitive taxa (Ephemeroptera, Odonata and Trichoptera) for the plant associated macroinvertebrates also showed the expected decrease in the highest trophic level, but it can only be applied to the freshwater sites, since these groups were very scarce in the brackish lakes. 
SEDIMENT

a)

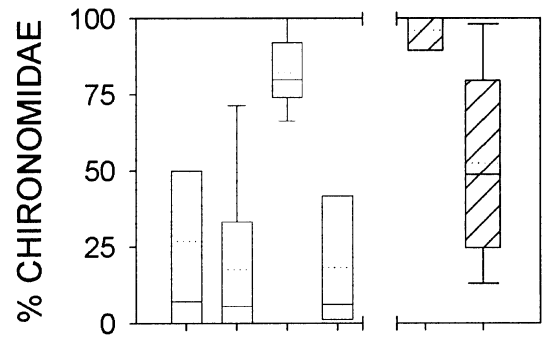

b)

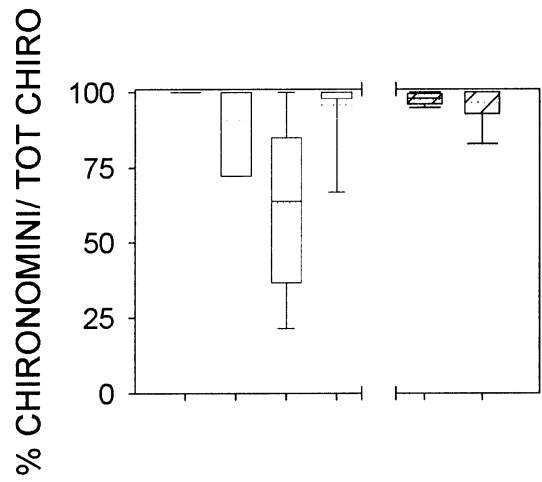

c)

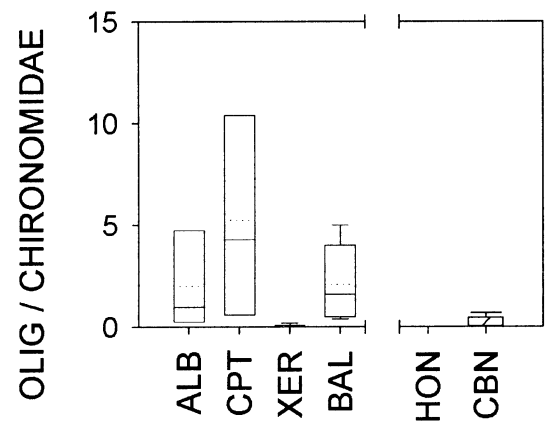

PLANT
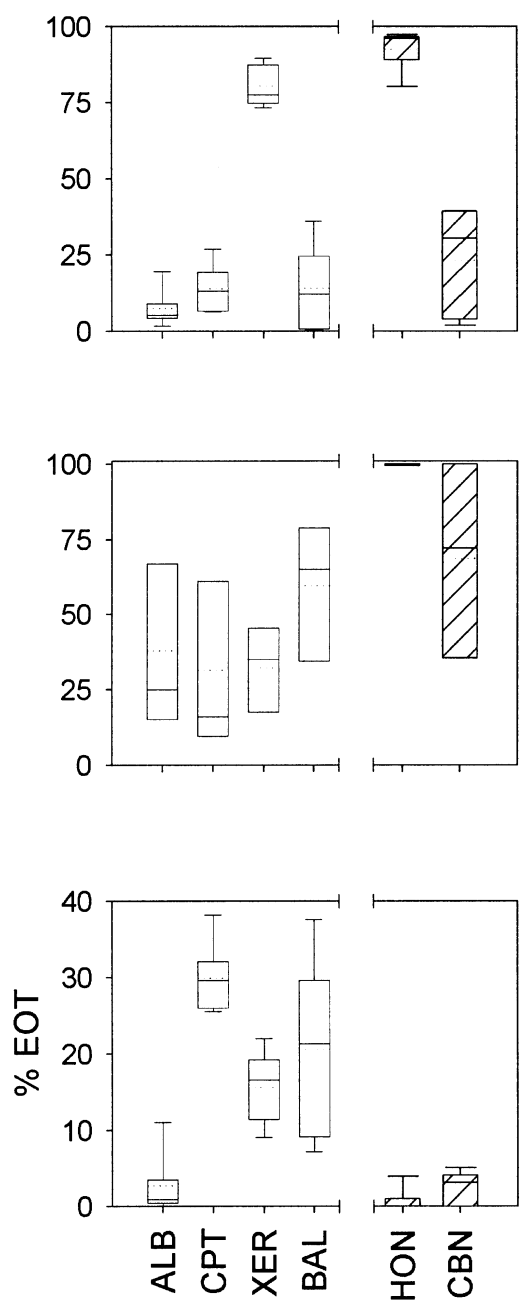

Fig. 4. Box plots (as in figure 3) of macroinvertebrate groups percentages and ratios used as quality indexes calculated separately for sediment and plant associated samples. (a) percentage of Chironomidae over total macroinvertebrates, (b) percentage of Chironomini over total of Chironomidae and (c) Oligochaeta:Chironomidae ratio for sedimentary macroinvertebrates and percentage of Ephemeroptera, Odonata and Trichoptera (EOT) for plant associated macroinvertebrates. Sites are coded as in figure 1.

\section{Discussion}

The six studied sites presented great differences especially in sediment macroinvertebrates. Dominant groups were tubificids and naidids in the most eutrophic sites (ALB and CPT), crustaceans and gastropods in the best preserved sites (BAL and CBN), and chironomids in the semi-permanent sites with highest water level fluctuations (XER and HON). Gastropods and large insects were most important in plants, the latter being much more abundant and diverse in freshwater sites. Certain oligochaeta, isopoda and anphipoda were exclusive of sediment.

In the best preserved sites a diverse and endemic fauna existed. Dugastella valentina is of particular conservation interest as it is an endemic decapod. In this study it was found only in BAL where it reaches high densities and is always associated with plants. This species has a very restricted distribution only 
known from the Valencian Comunity (Sanz \& Gómez 1984). Given the increasing deterioration of the habitats of this species, an effort is needed to preserve them, although in some cases they are already in protected areas, such areas lack effective pollution control and conservation measures. Associated to this species there are also several species with great biogeographical interest (endemic or with restricted distribution): Melanopsis tricarinata and Echinogammarus pacaudi. The presence of a singular community in the sediment of BAL is also remarkable, here the tanaidacean Heterotanais oerstedii is dominant and is accompanied by other species of crustaceans, the isopod Cyathura carinata, exclusive of the sediments, and Gammarus aequicauda which was found also in the plant samples but in smaller numbers. BAL represents the best preserved site among the studied wetlands. Here the community of spring pools, typical of these coastal planes, can still be found. CBN, which is oligotrophic too, showed a specific community which is characteristic of more brackish waters with Myosotella myosotis, $\mathrm{Pa}$ laemonetes zariquieyi, Hediste diversicolor and Corophium sp. CPT and ALB represent two examples of the eutrophication of the coastal water bodies, as well as a reduction of conductivity due to irrigation transformations in their surroundings. ALB is already in the turbid state.

Variability among different samples within the same site could result from the heterogeneity among and within habitats, indicating the importance of habitat differences such as plant density and structure, closeness of the sediment to reed belt, etc. (Cyr \& Downing 1988, Kornijów \& Gulati 1992, Cattaneo et al. 1998, Cheruvelil et al. 2000, White \& Irvine 2003). The general view of Peeters et al. (2004) that biotic factors are more important at a local scale and environmental factors determine distribution of species at larger scales may explain our results. In our study sites the macroinvertebrate communities responded to changes of environmental variables along the Valencian coast (salinity, hydroperiod length, eutrophication). In addition, within sites, the biological characteristics (plant density, structure, etc.) provided a certain variability among samples. This heterogeneity was much higher in the sediment samples than in plant associated ones. Several reasons could explain this fact. In heterogeneous habitats, the increasing sampling effort could increase the number of different microhabitats sampled and thus the species number. This could be the case of plant associated macroinvertebrates, in which differences between mean number of species per sample and jackknife estimates were highest in the freshwater permanent lakes with more diverse plant communities
(BAL and CPT). However, in the case of sediment samples, the higher jackknife estimates values can be due not only to heterogeneity of microhabitats, but also to the small scale type of sampling when using the core. The area sampled with the core is too small to evaluate the total number of species of the complex sedimentary community and the species number increases when samples are added, due to species with sparse populations. Various studies found that hand-net sweeps collect larger number of taxa than corers (Cheal et al. 1993, García-Criado \& Trigal 2005), although coring is appropriate in studies targeting specific benthic groups. In the sediment samples the sites with more extreme conditions (the hypertrophic ALB and the semi-permanent and brackish HON) had less marked differences between the number of species per sample and the jackknife estimator.

The jackknife estimate of diversity index are moderately higher than mean diversity per sample in some of the sites, in sediment samples they are higher in eutrophic lakes where low density makes the area sampled with the core too small. On the other hand the jackknife estimate of diversity for BAL sedimentary macroinvertebrates resulted abnormally small due to the high density of tanaidacens in all samples. However the increased value of the jackknife estimate with respect to the mean diversity of the plant associated macroinvertebrates, in BAL as well as in CBN, indicates a high heterogeneity of the plant associated macroinvertebrates, which is the expected result for these oligotrophic ecosystems.

The results of correspondence analysis indicated that salinity was the most important environmental variable responsible for community composition among different study sites, as occurs in other studies on coastal (Arnold \& Ormerod 1997, Frisch et al. 2006) or inland (Boronat et al. 2001, Piscart et al. 2005) aquatic ecosystems where a salinity gradient exists. In our results, brackish water sites supported a higher abundance of Gastropoda, Chironomidae and Crustacea while Ephemeroptera, Coleoptera and Heteroptera more sensitive to salinity (Williams \& Williams 1998, Hart et al. 1991) were almost excluded from these habitats.

According to Moss (1994), saline lakes fall into two groups: primarily saline, where water salinity is increased by evaporation and modified by precipitation of salts and secondarily or brackish because of the mixing with sea water. In our study sites, HON corresponds to the primarily saline group and $\mathrm{CBN}$ to the brackish group. In CBN, although it is brackish, steady conditions and low contamination levels allow to maintain diversity values comparable with freshwater sites. 
Williams et al. (1990) found that the reduction of species richness due to salinity in inland waters is a question of scale and does not apply at intermediate levels. CBN transitional waters of moderate salinity low trophy has a well-structured sediment community which includes a high number of species belonging to different trophic groups (detritivores, herbivores and predators). Thus species richness and diversity in this paralic environment is comparable to that of freshwater sites.

The hydrological regime arises as second significant factor affecting macroinvertebrate communities in the correspondence analysis. According to Moss (1994), in arid areas, basins are small and shallow because of their tendency to dry up, and may cause a stress that reduces biodiversity. This is the case of HON, which beside their mesosaline and mesotrophic conditions, can dry up at the end of summer, thus it showed the lowest diversity and species richness in sediments and plant associated macroinvertebrates. Another semi-permanent system is XER, here diversity index is relatively high but species richness for plant associated macroinvertebrates is very low.

Despite these clear differences in salinity and hydroperiod length, the variables related to eutrophication play an important role as well in structuring the communities in the our study sites. The sediment macroinvertebrate density has been demonstrated to be a useful tool in the assessment of eutrophication; it declines in highly eutrophicated sites because of anoxic conditions, whereas peak densities are found at intermediate trophic levels (Johnson \& Brinkhurst 1971, Romo et al. 2004). In the highly eutrophic shallow lakes, as in ALB and CPT sediments become anoxic and specially in ALB without submerged macrophytes the soft sediment is often disturbed by wind or fishes becoming an unsuitable habitat for invertebrates (Jónasson \& Lindegaard 1979, Moss \& Timms 1989), thus densities are very low. Much of the literature describes the eutrophication in shallow water bodies as a change from benthic to pelagic production (Vadeboncoeur et al. 2001). Lindegaard (1994) also found that benthic production in shallow lakes made up $80 \%$ of total secondary production. Our results showed that lower trophic levels had the highest densities of macroinvertebrates in the sediment, but the abundance of plant associate macroinvertebrates had not significantly differences with trophic level. Probably the sediment reflects the effect of eutrophication better or faster than plant associated samples. Other stressors such as changes in water level may affect first the column of water near the surface and this effect could be difficult to separate from eutrophication, thus the expected increase of abundance with moderate eutrophication, where light is still sufficient for periphyton primary production (which represents an important resource for macroinvertebrates) was not evident from our data.

Diversity is also reduced by eutrophication, especially marked in ALB and HON, although in the latter other factors such as temporality and salinity are also influencing this parameter.

We did not find clear relationship between other tested index and ecological quality (Fig. 4) because our six locations showed high differences in other factors influencing the values of those index.

When percentages or ratios between macoinvertebrate groups are tested in freshwater sites, they may be useful indicators of ecological quality (García-Criado et al. 2005), but we found that they are strongly influenced by salinity and permanence of the waters. For instance, the ratio Oligochaetes:Chironomids used to asses biological recovery of lakes (Lang 1990, 1998, Lang \& Lods-Crozet 1997), due to the expected drop in the sediment of chironomids with respect to oligochaetes with lake fertility (Kornijów et al. 2003) could only be applied to freshwater permanent sites, because oligochaetes were extremely scarce specially in the semi-permanent Chara-dominated locations. These locations were dominated by Chironomidae, in these sites an analysis at a lower taxonomical level of Chironomids, would be necessary to discriminate eutrophication. However oligochaetes were much more abundant in the more eutrophic freshwater sites, not only in the sediment but also among plants (Table 2). One of the more abundant species in these sites was Dero digitata has been related to areas abundant in organic matter (Särkkä 1989). This ratio as well as the percentage of sensitive species (EOT) showed a great variability and very low values in brackish an in semipermanent sites.

Results of system variables and biotic indices were very dependent on the characteristics of water bodies, other than trophic level, such as salinity and water level fluctuations. These environmental differences contribute to sustain regional biodiversity, as in other small aquatic habitats (Oertli et al. 2002). In the arid Mediterranean climate, water is a scarce resource, and anthropogenic hydraulic modifications are very large. Conservation of natural hydrological regimes and water connectivity are among the most important factors for the preservation of biodiversity, beside eutrophication and pollution in general. 


\section{Acknowledgements}

We are very grateful to the ECOFRAME Valencian team (C. Ferriol, S. Romo, E. Vicente and M. J. Villena). We wish also to thank F. Robles and A. Sanz for their help in identification of Gastropoda and Decapoda taxa, respectively. This study was partially supported by a contract from the European Commission (ECOFRAME, CE Environment Project EVKI-1999-00261).

\section{References}

Arnold S.L. \& Ormerod S.J. 1997. - Aquatic macroinvertebrates and environmental gradients in Phragmites reedswamps: implications for conservation. Aquatic Conserv: Mar. Freshw. Ecosyst., 7, 153-163.

Batzer D.P., McGee M., Resh V.H., \&. Smith R.R. 1993. Characteristics of invertebrates consumed by mallards and prey response to wetland flooding schedules. Wetlands, 13, 41-49.

Blanco S., Romo S., Villena M.J. \& Martínez S. 2003. - Fish communities end food web interactions in some shallow Mediterranean lakes. Hydrobiologia, 506-509, 473-480.

Boronat L., Miracle M.R. \& Armengol X. 2001 . - Cladoceran assemblages in a mineralization gradient. Hydrobiologia, 442, 75-88.

Cattaneo A., Galanti G., Gentinetta S. \& Romo S. 1998. - Epiphytic algae and macroinvertebrates on submerged and floating-leaved macrophytes in an Italian lake. Freshwat. Biol., 39, 725-740.

Cheal F., Davis J.A., Growns J.E., Bradley J.S. \& Whittles F.H. 1993.The influence of sampling method on the classification of wetland macroinvertebrate communities. Hydrobiologia, 257, 47-56.

Cheruvelil K.S., Soranno P.A., \& Serbin R.D. 2000. - Macroinvertebrates associated with submerged macrophytes: sample size and power to detect effects. Hydrobiologia, 441, 133-139.

Cyr H. \& Downing J.A. 1988. - The abundance of phytophilous invertebrates on different species of submerged macrophytes. Freshwat. Biol., 20, 365-374.

Frisch D., Moreno-Ostos E. \& Green A. 2006. - Species richness and distribution of copepods and cladocerans and their relation to hydroperiod and other environmental variables in Doñana, southwest Spain. Hydrobiologia 556, 327-340.

García-Criado F. \& Trigal C. 2005. - Comparison of several techniques for sampling macroinvertebrates in different habitats of a North Iberian pond. Hydrobiologia, 545, 103-115.

García-Criado F., Bécares E., Fernández-Aláez C. \& FernándezAláez M. 2005. - Plant-associated invertebrates and ecological quality in some Mediterranean shallow lakes: implications for the application of the EC Water Framework Directive. Aquatic Conserv: Mar. Freshw. Ecosyst., 15, 31-50.

Hart B.T., Bailey P., Edwards R., Hortle K., James K., McMahon A., Meredith C., \& Swadling K. 1991. - A review of the salt sensitivity of the Australian freshwater biota. Hydrobiologia 210,105-144.

Heltshe J.F. \& Forrester N.E. 1983. - Estimating species richness using the Jackknife procedure. Biometrics, 39, 1-11.

Johnson M.G. \& Brinkhurst R.O. 1971. - Benthic community metabolism in Bay Quinte and Lake Ontario. J. Fish. Res. Bd. Canadian., 28, 1715-1725.

Jonasson P.M. \& Lindegaard C. 1979. - Zoobenthos and its contribution to the metabolism of shallow lakes. Arch. Hydrobiol. Beih. Ergebn. Limnol., 13, 162-180.

Kornijów R. \& Gulati R.D. 1992. - Macrofauna and its ecology in Lake Zwemlust, after biomanipulation. 2. Fauna inhabiting hydrophytes. Arch. Hydrobiol., 123, 349-359.

Kornijów R. 1989. - Seasonal changes in the macrofauna living on submerged plants in two lakes of different trophy. Arch. Hydrobiol., 117, 49-60.
Kornijów R., Radwan S., Tarkowska-Kukuryk M. \& Kahlan G. 2003. - Zoobenthos of ecotonal zones in several lakes of different trophic status (the region Polesie Lubelskie, Eastern Poland). Polish Journal of Ecology, 51, 237-246.

Lang C. \& Lods-Crozet B. 1997. - Oligochaetes versus chironomids as indicators of trophic state in two Swiss lakes recovering from eutrophication. Arch. Hydrobiol. 139, 187-195.

Lang C. 1990. - Quantitative relationships between oligochaete communities and phosphorus concentrations in lakes. Freshwat. Biol., 24, 327-334.

Lang C. 1998. Using oligochaetes to monitor the decrease of eutrophication: the 1982-1996 trend in Lake Geneva. Arch. Hydrobiol., 141, 447-458.

Lindegaard C. 1994. The role of zoobenthos in energy flow in two shallow lakes. Hydrobiologia, 275/276, 313-322.

McQueen D.J., Post J.R. \& Mills E.L. 1986. - Trophic relationships in freshwater pelagic ecosystems. Canadian Journal of Fisheries and Aquatic Sciences, 43, 1571-1581.

Moss B. \& Timms M. 1989. - Predation, sediment stability and food availability as determinants of the benthic invertebrate fauna in two shallow lakes. Hydrobiologia, 185, 249-257.

Moss B. 1994. - Brackish and freshwater shallow lakes - different systems or variations on the same theme? Hydrobiologia, 276, 1-14.

Moss B., Beklioglu M., Carvalho L., Kilinc S., McGowan S. \& Stephen D. 1997. - Vertically-challenged limnology; contrast between deep and shallow lakes. Hydrobiologia, 342/343, 257-267.

Moss B., Stephen D., Alvarez C., Becares E., Van de Bund W., Collings S.E., Van Donk E., De Eyto E., Feldmann T., FernándezAláez C., Fernández-Aláez M., Franken R.J.M., García-Criado F., Gross E.M., Gyllstrom M., Hansson L.A., Irvine K., Järvalt A., Jensen J.P., Jeppesen E., Kairesalo T., Kornijów R., Krause T., Künnap H., Laas A., Lill E., Lorens B., Luup H., Miracle M.R., Nõges P., Nõges T., Nykänen M., Ott I., Peczula W., Peeters E., Phillips G., Romo S., Russell V., Salujõe J., Scheffer M., Siewertsen K., Smal H., Tesch C., Timm H., Tuvikene L., Tonno I., Virro T., Vicente E. \& Wilson D. 2003. - The determination of ecological status in shallow lakes- a tested system (ECOFRAME) for implementation of the European Water Framework Directive. Aquatic Conserv: Mar. Freshw. Ecosyst., 13, 507-549.

OECD 1982. - Eutrophication of waters. Monitoring, assessment and control. OECD, Paris, $154 \mathrm{p}$.

Oertli B., Joye D.A., Castella E., Juge R., Cambin D. \& Lachavanne J.B. 2002. - Does size matter? The relationship between pond area and biodiversity. Biol. Cons., 104, 59-70.

Oertli B., Biggs J., Cereghino R., Grillas P., Joly P. \& Lachavanne J.B. 2005. - Conservation and monitoring of pond biodiversity : introduction. Aquat. Conserv. Mar. Freshwat. Ecosyst., 15, 535-540.

Peeters E.T.H.M., Gylstra R. \& Vos J.H. 2004. - Benthic macroinvertebrate community structure in relation to food and environmental variables. Hydrobiologia, 519, 103-115.

Piscart C., Moreteau J.C. \& Beisel J.N. 2005. - Biodiversity and structure of macroinvertebrate communities along a small permanent salinity gradient (Meurthe River, France). Hydrobiologia, 551, 227-236.

Puchalski W. 1987. - Phytoplankton assemblages in afterexploitation reservoirs. PhD Thesis, Institute of Ecology PAS, Dziekanow Lesny, 205 p.

Romo S., Miracle M.R., Villena M.J., Rueda J., Ferriol C. \& Vicente E. 2004. - Mesocosm experiments on nutrient and fish effects on shallow lake food webs in a Mediterranean climate. Freshwat. Biol., 49, 1593-1607. 
Sanz A. \& Gómez P. 1984. - Distribución geográfica de Dugastella valentina (Ferrer Galdiano, 1924) (Crustacea: Atyidae). Limnética, 1,336-339.

Särkkä J. 1989. - Meiobenthic naidid and aelosomatid oligochaetes from the profundal zone, and relations of species to eutrophication. Hydrobiologia, 180, 185-190.

Scheffer M. 1998. - Ecology of Shallow Lakes. Chapman \& Hall. London. $357 \mathrm{p}$.

Vadeboncouer Y., Lodge D.M. \& Carpenter S.R. 2001. - Whole lake fertilization effects on distribution of primary production between benthic and pelagic habitats. Ecology, 82, 1065-1077.
White J. \& Irvine K. 2003. - The use of mesohabitats and their macroinvertebrate assemblages in the ecological assessment of lakes. Aquatic Conserv: Mar. Freshw. Ecosyst., 13, 331-351.

Williams D.D. \& Williams N.E. 1998. - Aquatic insects in an estuarine environment: densities, distribution and salinity tolerance. Freshwat. Biol., 39, 411-421.

Williams W.D., Boulton A.J. \& Taaffe R.D. 1990. - Salinity as a determinant of salt lake fauna: a question of scale. Hydrobiologia, 197, 257-266.

Zahl S. 1997. Jackknifing an index of diversity. Ecology, $58,907-913$ 